\title{
三重県の雑煮に関する考察（1）
}

\author{
堀田千津子 \\ (鈴鹿医療科学大学)
}

\section{A Study on Zouni in Mie Prefecture (Part 1)}

\author{
Chizuko Hotta \\ Suzuka University of Medical Science \\ 1001-1k ishioka-cho, Suzuka-shi, Mie 510-0226 \\ ₹ 510-0226 三重県鈴鹿岸岡町1001-10
}

The aim of this study is to analyze the "Zuoni" in Mie Prefecture.

1) "Zouni" in Mie, according to seven books of local history, has existed as round glutinous cake, a square glutinous cake, a clear soup, miso soup and adzuki beans.

2) Most families prepared it as an Osachi dish (83.7\%).

but the age family doesn't prepare for the one acodding to const ruction family the ratio shew $19.1 \%$.

3) Most families celebrated with "Zouni", the high scoer was $95.6 \%$ for New Year Day's breakfast.

4) The "Zouni" form of glutinous cake has been fried for example the Hokusei, Chiusei and Nansei areas have a square glutinous cake, The Iga, Isesima and a part of the Nansei area have a round glutinous cake.

5) The "Zouni" Soup has been referred to, for example, the Hokusei and Nansei areas have a "Clear Soup", the Chiusei and Iga areas have a "Miso Soup", and the Toba area has "Anpin"

\section{1. 緒言}

現在の社会状況や生活環境等のめまぐるしい移変に伴 い, 食生活に打いても必然的に日々変化を続けており， その中で各地域に住む人々の知恵と工夫により生み出さ れたいろいろな料理が, 伝えられて伝統料理と呼ばれる ようになっている.その伝統料理の中で昔ながらの料理 形態が比較的正確に今日まで伝えられ, しかもどの地域 にも存在する料理のひとつに「雑煮」がある.

三重県は六県に隣接し, 関東圏と関西圈のほ注中央に
位置し, 東西の文化の影響をらける「境界」に位置して いる1)。その影響と思われるが北勢地方の雑煮は, 角餅 にすまし仕立てであり,「伊勢の菜雑煮」といら言葉も ある. 増木はこの「伊勢の菜雑煮」を「切り餅 (角餅)」, 「菜」「「㽜油」の三要素を持った雑煮としている2). また, 大川の調査によると, 安芸郡の安濃地区では「伊 勢の菜雑煮」とは異なり, 汁はみそ汁であり, 具は大根 とさといもが用いられていると報告している31.

更には, 南勢に位置する熊野市飛鳥地区では, 切り餅 に醤油味は「伊勢の菜雑煮」と共通しているが，具には 
ねぎ，コンニャク，豆腐などが加わっている2).

このように, 三重の雑煮は「境界」に位置しているこ とから豊かな郷土食がみられる。

そこで，筆者は今回三重の雑煮を取り上げ，どのよう に伝承されているか地域生活の本質にふれながら, 現在 の正月の食生活の様子を明らかにすることを目的に研究 を行った．第 1 報では戦前の雑煮と戦後の雑煮から餅の 形と汁について分析した。 また，お雑煮の具については 第 2 報に委ねた.

\section{2. 調查方法}

1）戦前の雑煮については郷土誌などから検索した.

2）戦後の雑煮について三重県に在住する大学生の家 庭の調理担当者を対象にアンケート調査を配布して調査 した、世帯数は 435 世帯, 調査時期は平成 10 年 1 月〜 2 月, 内容はおせち料理の準備の有無, 雑煮の契食状況, 雑煮の餅形, 汁, 具など 20 項目とした. 分析方法は $x^{2}$ による有意差判定と分布図を用いた。また，アンケート 調査は家族構成の影響をみるために核家族と複合家族に 分類して行った.

\section{3. 結果考察}

（1）郷土誌などからみる雑煮について（表 1 ）

表 1 郷土誌などからみる雑煮

\begin{tabular}{|c|c|c|c|c|}
\hline 文 献 名 & 喫食日 & 餅形 & 汁 & 具 \\
\hline \multirow[t]{2}{*}{ 桑名の民族 } & 三が日餅 & & & \\
\hline & のある間 & 角 & 濃い口奨油 & 小松菜 \\
\hline 菰野町史 & 正月 & 角 & 奨油 & マナ・小松菜 \\
\hline 庄野郷土誌 & 元旦 & 角 & 奨油 & 菜つ葉·野菜 \\
\hline 志摩郡·和具の食生活 & 年の初め & 丸 & 奨油 & なっぱ \\
\hline 三重の伝統料理 & 元旦 & & アズキ & \\
\hline 三重民族研究会報 & 三が日 & 角 & 味噌 & 大根·里芋 \\
\hline 水沢野田町の民俗 & 三が日 & 角 & たまり奨油 & あげ・なっぱ \\
\hline
\end{tabular}

\section{- 『桑名の民族（大正初期』）}

初詣では地元の氏神が主な対象となり，遠出をするこ とはあまりなかった. 元旦の初詣としては, 伊勢神宮は 距離的に遠かった.

ハツミズ（都市部ではワカミズといら）を汲む人は， 地区によって一家の主人といらところあれば，主婦とい らところもあり，一定しない。この水はまず神仏に供え， 雑煮炊きや書き初め用に供えた，正月後の朝食は餅のあ る間は雑煮を食べた。正月の雑煮は濃口㽜油で調味した すまし汁に小松菜を入れたもので，雑煮に使う小松菜を 特に正月菜といった. 町家では, 正月菜を年末に買って, 正月三日間し拈れないように新聞に包み，寒い場所に保
存した。餅はのし餅を切った長方形の角で，水から煮る 家もあれば湯に入れて煮るところもあった。

・『菰野町史 (昭和初期)』5!

昔は大抵の家が，打鏡さんや雑煮に使う正月用の餅を 自宅で搗いていた，餅を搗く日は各々の家で大体決まっ ていたが，三十日に搗くことが多かった．雑煮の餅はの し餅を角切りにしたものが使われるが，糯米にらるちを 混ぜたタガネを作る家も多い，また出し汁はかつ敃節や 煮干しでとり，薄めに酱油で味付けをし，鍋の底に餅が くっつかないように，マナか餅菜を鍋の底にいれて，そ の上に餅をのせて煮込む．食べるときに削りかつ拈を上 から振りかける家もある、縁起を担いで（一年間まめで 暮らしたいといら願望から）秋収穫したあぜ豆の殼（マ メガラ）を残しておいてそれで雑煮を炊いた。

\section{・『庄野郷土誌』6)}

雑煮は室町時代に始まり, 元禄時代から盛んになった。 家風により作り方はまちまちである。なんでもめでたい 意味のものをごたごたに入れた汁へのし餅を入れて食べ ることは長生きするようにという意味をもっていた。の し餅とは，餅を丸めないで板状に薄く延ばしたもので， 角にきったものを言い，菜っ葉などの野菜を入れ，䚚節 のだしと酱油で煮たものである，元旦の早朝は，宮さん へ打参りし, 一家揃って雑煮や御屠蘇を頂いた後, 親戚 や友人，世話になった人に年頭のあいさつをする.

·『志摩郡 · 和具の食生活（三重県志摩郡の大正 12 年から昭和 9 年頃の生活)』7)

「年の初めの若水，よろずの宝を汲み上げる」と いって, 寺屋 (地名) の井戸で綱を引いて若水を汲 む.その水で茶をたて，仏壇に供える、神棚に置い た「はすの膳 (八寸の膳)」に盛られた雑煮用の丸 餅をおろし，水で洗って雑煮に使う。出し汁は鰹節 に酱油で味を付け，鍋の底になっぱ（菜葉）を敷い て餅を縦に並べて煮る。

\section{・『三重の伝統料理』8)}

神島では正月に若水くみが行われる．若水とは一年の 邪気をはららため, 元旦や立春の早朝に汲む水のことで, 神島では共同井戸で汲む，若水を汲むとき割り木を 3 本 持っていき，1 本は戸端で然やし，1 本は井戸端におき， 残りの 1 本は持ち帰りカンノモチをたくときに使う. カ ンノモチの小豆はユキヒラを使って時間をかけて炊かれ ていたが，現在はユキヒラから大ナべに変わっている．

若水を持ち帰ると, 若水に餅とあらかじめ煮て打いた 小豆を入れて，砂糖で甘く味付けされることからぜんざ いと変わらない.正月は小豆の赤と餅の白の紅白で祝う. 
若い人はぜんざいと呼ぶが小豆汁である。

・『三重民族研究会会報』(大正10年から昭和10年) ${ }^{3)}$

雑煮の汁と具の仕込又は暮れに行ら。汁はみそ汁であ る. 具としての大根は幾分厚めの輪切りとする. その大 根と丸のままの里芋, 家によっては油揚げを入れ, 味噌 を多く入れた汁で幾分辛い目とする。この雑煮にいれる 餅は岩域地区では丸餅，野口や荒木として浄土寺や村主 或いは砂法寺とほとんどの地区では尉斗 (角) 餅である.

\section{『水沢野田町の民族』9)}

野田の多くの家では，雑煮は角餅，あげ，なっぱもし くは, 白菜をたまり滰油で炊いて花かつをを散らす。雑 煮の仕度は，暮れの31日に女が三力日分の野菜の用意を し，あげは細く切っておく，それを正月三力日間，主人 が朝汲んでくる若水で雑煮にする. その際, 豆の木で火 をつけるものとされている。それは一年中，まめで健康 でいられるよらにといら意味である。

少ない資料であるが，以上から三重の雑煮は「丸餅」 「角餅」「すまし仕立て」「みそ仕立て」「小豆汁」が存 在し, 関東圏の「角餅・すまし仕立て」と関西圈「丸 餅・みそ仕立て」の食文化と異なり, 独自の食文化が存 在していたことが理解できる.

\section{(2) 戦後の雑煮について \\ 1) 調査対象者の特性}

調查対象者（料理担当者）の特性を表 2 に示した. 表 2 調査対象者の特性

\begin{tabular}{rcccccc}
\hline 年歯構成 & $20 \sim$ & $30 \sim$ & $40 \sim$ & $50 \sim$ & $60 \sim$ & $70 \sim$ \\
\hline $\mathrm{n}$ & 12 & 18 & 279 & 97 & 14 & 15 \\
$(\%)$ & $(2.8)$ & $(4.1)$ & $(64.1)$ & $(22.3)$ & $(3.2)$ & $(3.4)$ \\
\hline 家族構成 & \multicolumn{3}{c}{ 核家族 } & \multicolumn{3}{c}{ 複合家族 } \\
\hline $\mathrm{n}$ & \multicolumn{2}{c}{295} & \multicolumn{2}{c}{140} \\
$(\%)$ & & $(67.8)$ & & $(32.2)$ \\
\hline
\end{tabular}

対象者の年歯令は20 86歳で40歳代が最も多く, 平均は 47 歳士 8 歳であった。 また，家族形態は複合家族が 140 世帯 $(32.2 \%)$ に対し核家族は295世帯（67.8\%）を示 した。

\section{2 お おせち料理の準備}

おせちの準備の有無と各々の理由と準備の方法を表 3 に示した。今年のおせち料理を「準備した」は365世帯 (83.9\%) とほとんどの家族で準備されたのに対し，「準 備しない」は70世帯 (16.1\%) であった。家族構成別で は，核家族世帯に拈いて「準備しない」57世帯（19.3\%） を示し，複合家族世帯との間に $1 \%$ の有意差があった.

また，準備した世帯の内154世帯（42.2\%）が「手づ
表 3 おせち料理の準備

\begin{tabular}{|c|c|c|c|c|c|c|}
\hline & \multicolumn{5}{|c|}{ 核家族構成 } \\
\hline & & \multicolumn{2}{|l|}{ 全体 } & 核家族 & 複合家族 & $x^{2}$ 挨定 \\
\hline \multicolumn{7}{|l|}{ おせちの準備 } \\
\hline した & 365 & $(83.9)$ & 238 & $(80.7)$ & $127(90.7)$ & $* *$ \\
\hline しない & 70 & $(16.1)$ & 57 & $(19.3)$ & $13(9.3)$ & \\
\hline \multicolumn{7}{|l|}{ 準備の方法 } \\
\hline 手作り & 154 & $(42.2)$ & 92 & $(38.7)$ & $62(48.3)$ & \\
\hline 一部購入 & 189 & $(51.8)$ & 127 & $(54.2)$ & $62(47.2)$ & \\
\hline セット購入 & 17 & $(4.7)$ & 14 & $(5.9)$ & $3(2.4)$ & \\
\hline 戴く & 5 & $(1.4)$ & 3 & $(1.3)$ & $2(1.6)$ & \\
\hline \multicolumn{7}{|l|}{ 準備する主な理由 } \\
\hline 例年通り & 182 & $(40.9)$ & 113 & $(47.5)$ & $69(54.3)$ & \\
\hline 欠かせない & 70 & $(19.2)$ & 51 & $(21.4)$ & $19(15.0)$ & \\
\hline 伝統 & 54 & $(14.8)$ & 37 & $(15.5)$ & $17(13.4)$ & \\
\hline 家族の要望 & 22 & $(6.0)$ & 12 & $(5.0)$ & $10(7.9)$ & \\
\hline 来客のため & 13 & $(3.6)$ & 7 & $(2.9)$ & $6(4.7)$ & \\
\hline 事前できる & 13 & $(3.6)$ & 11 & $(4.6)$ & $2(1.6)$ & \\
\hline 華やか & 3 & $(0.8)$ & 3 & $(1.3)$ & $0(0.0)$ & \\
\hline その他 & 8 & $(2.2)$ & 4 & $(1.7)$ & $4(3.1)$ & \\
\hline \multicolumn{7}{|l|}{ 準備しない主な理由 } \\
\hline 面倒 & 21 & $(30.0)$ & 16 & $(28.1)$ & $5(38.5)$ & \\
\hline 外出 & 14 & $(20.0)$ & 12 & $(21.1)$ & $2(15.4)$ & \\
\hline 好みに合わない & 11 & $(15.7)$ & 9 & $(15.8)$ & $2(15.4)$ & \\
\hline 形式的でまずい & 4 & $(5.7)$ & 4 & $(7.0)$ & $0(0.0)$ & \\
\hline 腐敗の心配 & 1 & $(1.4)$ & 1 & $(1.8)$ & $0(0.0)$ & \\
\hline その他 & 19 & $(27.1)$ & 15 & $(26.3)$ & $4(70.8)$ & \\
\hline
\end{tabular}

注） $\mathrm{n}(\%), * * 1 \%$ 有意差

くり」で準備し正月を迎えている。しかし，今日では市 場に色とりどりの执せちが販売されており,执せちの「セ ット購入」は17世帯 $(4.7 \%)$, 必要に応じて「一部購入」 して整える世帯が189世帯（51.8\%）もあった。家族構 成別では差がみられなかった。

準備する理由は，第一に「例年通り」181世帯 (40.9 $\%)$ ，第二に「正月には久かせない」70世帯（19.2\%）， 第三「伝統的だから」54世帯（14.8\%）であった.

この例年通り，正月には久かせない及び伝統だからは， おせちの特徵をよく示している.このようにして今後も おせちの伝統が伝えられていくのであろう.

一方，準備しない理由の第一は「面倒だから準備しな い」21世帯 $(30.0 \%)$ ，第二は「外出するから」14世帯 (20.0\%) があげられ，外出は特に核家族にみられる正 月特有の事情であると考えられる。一方「面倒だから準 備しない」は先行研究 ${ }^{10)} に て$ 行事食などの晴食を家庭で 試みることが少ない世帯では調理, 食品購入計画の意識 が低調であり，既製調理依存を示したことから調理担当 者の精神面, 技術面などの負担が予想される.

\section{3）雑煮の喫食状況}


表 4 雑煮を祝いましたか

\begin{tabular}{lcc}
\hline 扣雑者を祝った & はい & いいえ \\
\hline 全体 & $416(95.6)$ & $19(4.3)$ \\
核家族 & $278(94.2)$ & $17(5.8)$ \\
複合家族 & $138(98.6)$ & $2(1.4)$
\end{tabular}

注） $\mathrm{n}(\%)$ ，核家族と複合家族には有意差はなかった。

表 5 正月三が日の雑煮喫食率

\begin{tabular}{lcccccc}
\hline & 朝食 & 朝食と昼食兼用 & 昼食 & 昼食と夕食 & 夕食 & 夜食 \\
\hline 元旦 & & & & & & \\
全体 & 60.0 & 26.2 & 13.0 & 1.2 & 9.4 & 1.4 \\
核家族 & 57.2 & 27.3 & 15.9 & 0.7 & 9.7 & 1.4 \\
複合家族 & 65.9 & 23.9 & 11.5 & 2.2 & 9.4 & 1.4 \\
\hline 二日目 & & & & & & \\
全体 & 46.6 & 18.8 & 11.3 & 0.0 & 8.2 & 1.2 \\
核家族 & 45.3 & 18.3 & 10.1 & 0.0 & 8.3 & 1.8 \\
複合家族 & 49.3 & 19.6 & 13.8 & 0.0 & 8.0 & 0.0 \\
\hline 三日目 & & & & & & \\
全体 & 41.1 & 11.1 & 9.4 & 0.0 & 6.0 & 1.0 \\
核家族 & 38.0 & 10.4 & 8.7 & 0.0 & 6.5 & 0.0 \\
複合家族 & 47.1 & 10.4 & 9.7 & 0.0 & 5.1 & 1.4 \\
\hline
\end{tabular}

注）数值は\%, 核家族と複合家族には有意差はなかった.

神との直会に由来があると言われる雑煮は新年の行事 の献立の中でも最も重要な意味を得, 元旦の朝, 神に供 えた年だなの魚や海産物のコンブ，アワビ，ナマコなど の下がりものを鏡餅とごった煮して食べたのが原形で室 町時代には「烹雑」といわれていた11).

雑煮の鿄食について表 4 ，表 5 に示した．表 4 に示す ように，雑煮で祝ら世帯は416世帯（95.6\%）とほとん

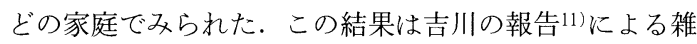
煮を食べる世帯「全国平均95\%」と一致した.

また，表 5 に示すよらに，雑煮を何時食するか食事別 の契食率では, 元旦の朝の契食が約 $60 \%$ と最も高く, 朝 食と昼食の兼用を加えると $90 \%$ 程になり，雑煮で新年を 祝ら意識が高いと推察でさる. 元旦の朝に続き二日目の 朝食, 三日目の朝食の順で食され, 朝食に用いられてい ることも理解できる. 家族構成別では差が得られなかっ た.

\section{4 ）雑煮の餅について}

三重県は，地理上から東西の検討をすると東海地方に 属し，東日本の一番西端にある。また，言葉の上からは 北勢地域の愛知県よりを除いた汪とんどの地域は,アク セントが関西であり, 文化圏は奈良, 京都, 大阪の影響 をうけている，食生活面では東と西が入りまじっている 1).

雑煮の餅の形を全国的に見た場合，東海を境に東がの
し餅を切った「角餅」, 西に「丸餅」が存在する12).

図 1 に餅の形の分布を示した。「角餅」は三重県全域 にみられるが, 北勢地域の藤原町, 北勢町, 大安町, 東 員町, 多度町, 桑名市などと美里村, 白山町, 一志町, 久居市などの中勢地域と紀伊長島町, 海山町などの南勢 地域では「角餅」のみである。一方「丸餅」は伊賀町， 上野市, 島ケ原町などの伊賀地域と伊勢, 鳥羽市, 磯部 町の伊勢志摩地域之南勢地域の尾鷲市, 熊野市, 御浜町 にみられた。

この結果は大川の大正時代の分布図 ${ }^{13)}$ おび前述の郷 土誌などの結果とほぼ同傾向を示した.

北勢 ·中勢地域の「角餅」は関東圈の文化が陸伝いに 南下し, 鈴鹿と亀山の境まで伝わったと考えられる.こ れに対し, 伊賀地方は三重県の西北部にあり, 滋賀, 京 都, 奈良の各県に接し, 古く奈良東大寺の荘園があり, 地理的にも京や奈良の都との結びつきが古くから強かっ たと思われる.

上野市の古老から「花びらもち」といら言葉を聞くこ とができた．「花びらもち」は, 押し餅ともいわれ，丸 餅を手の平で押し花弁形の薄餅にしたものである。かつ ては伊賀地域全域で行われた風習であったよらだが，現 在は古老の間で角餅を手の平で押して「花びらもち」に みせて用いられている程度であった，増木によると「花 びらもち」の起こりは, 室町時代の一時期に朝廷の経済 


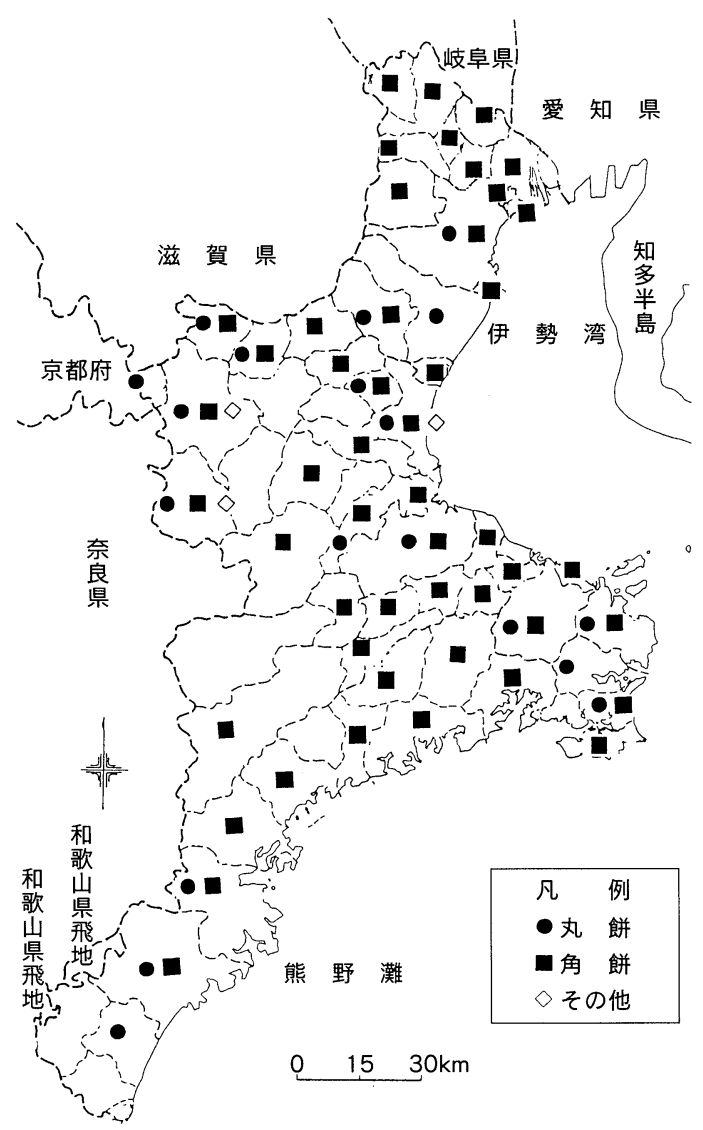

図 1 餅の形の分布

力が衰え, 御所の雑煮の餅が丸餅から餅花びらにかわつ たとされている．これは丸餅に比べて糯米の量が少なく て済むので切餅の普及は餅を一個一個丸めていくといら 人手 (人件費) の節約のほかに材料費の節約になったと いら22. このよらに丸餅を薄く押すことで豪華にみせた といらことは人々の生活の知恵と工夫の結果だとしてい $ろ^{2)}$.

伊勢志摩地域の「丸餅」は他の地域から丸餅が伝播し たといらより，伊勢志摩地域が神の住む場，すなわち， 伊勢神宮と関わった宗教的結び付きで餅が丸餅であった と考えられる. 奥村 $\left.{ }^{14}\right)$ は餅を丸（鏡餅）〈することは神 前に供えるの意のほか, 望月（満月）になぞらえ，欠け たることのない縁起の良さを求めたものであるとしてい る、また，丸餅を家族一緒に食べることは家庭円満につ ながるという。

熊野灘沿岸で「角餅」が多くみられたが, 熊野市五郷, 木本で「丸餅」を食するところがあった。この熊野市は
周冊が山で囲まれた盆地の地形区域で, 古くは桃崎から の峠を越える生活で奈良と盛んに交流してきた所であ り，奈良の丸餅が伝わったと考光られる。

\section{5) 雑煮の汁について}

雑煮の汁の分布を図 $2 ， 3$ に示した。餅ほどに明瞭に 分れていないが, 北勢地域の藤原町, 北勢町, 大安町, 桑名市, 川越町, 楠町, 菰野町, 鈴鹿市之南勢地域の紀 伊長島町, 尾鷲市が「すまし仕立て」で伊勢志摩地域の 「小豆汁」が僅かであるがみられた。

北勢地域のすまし仕立ては, 餅の形と同様に関東圏の 文化が陸伝いに南下し, 鈴鹿と亀山の境まで伝わった考 えられる。

北勢地域の南部から中勢および伊賀地域に「味増汁仕 立」がみられた。「味増汁仕立て」は伊賀, 初瀬, 和歌 山街道の旧街道が考えられる. 街道の多くの人々が伊勢 神宮参拝などで往来し, それと共に近畿圏より味増汁仕

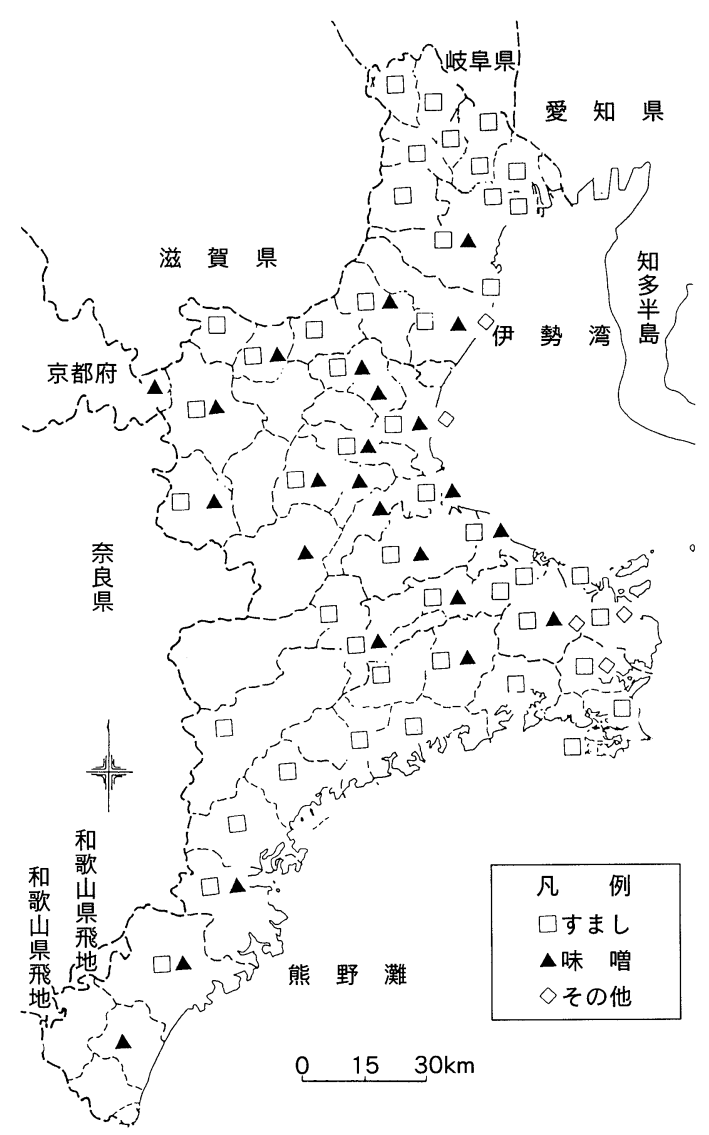

図 2 雑煮の汁の分布 


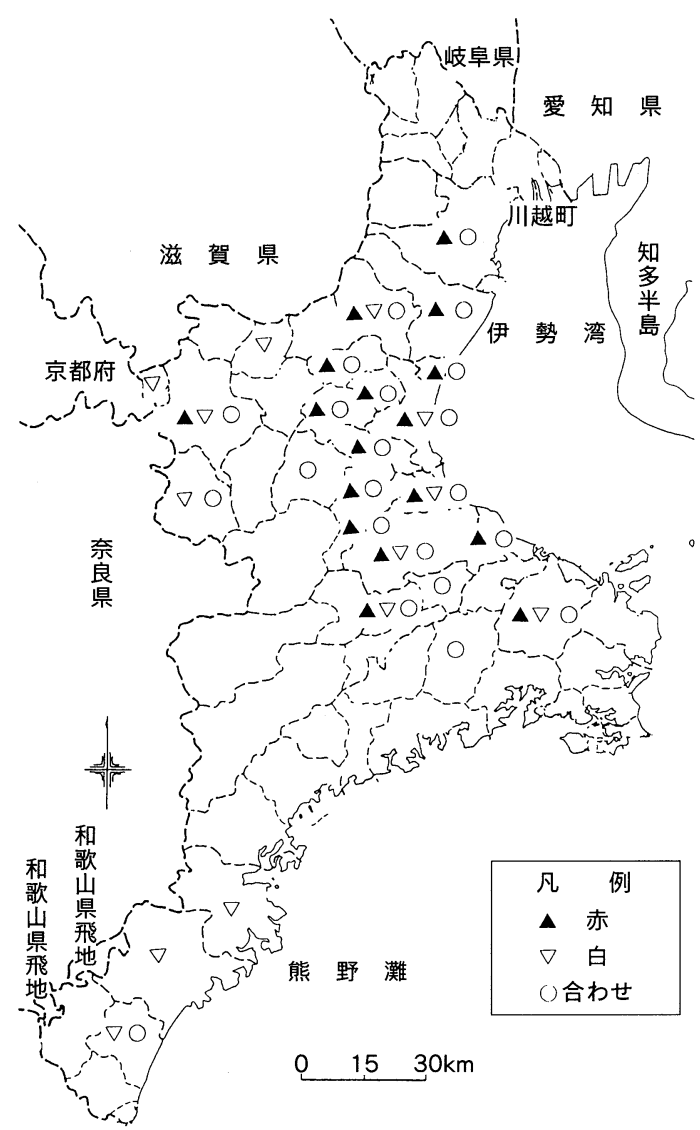

図 3 味噌の種類別分布

立ての雑煮が伝わったと思われる。しかし，一般的には 白味増仕立ての雑煮であったと考えられるが，しかし， 多気町, 勢和村, 飯南町などでは赤味増, 合わせ味増を 使用しているといら回答を得た。

この地域では明治頃から味増玉がつくられており，昭 和初期には隣近所で共同して味増, 奨油の仕込みが行わ れ，味噌は一年分作られていたことから，自家製の味増 が白味噌に変わって用いられ，今日の赤味噌雑煮として 食されていると推測される。あた，合わせ味増は大川の 大正時代の分布図 ${ }^{13)}$ および前述の郷土誌などの結果から は得られないことから, 赤味噌と白味噌に比べて比較的 新しい食文化と言える。

尾鷲市と熊野の一部では,「味増仕立て」の雑煮をみ るが,これは餅の形と同様に奈良の影響が考えられるが, 尾鷲, 紀伊長島町にも味増仕立てがあることは，「打伊 勢参らば，熊野も参れ」といら言葉が語るよらに, 熊野 街道と関わりがあるのだろらか。 また鳥羽市近辺のすま
し仕立ては，中世以来の海上交通との結び付きで関東圈 のすまし雑煮が伝えられ，北勢および中勢の陸づきとは 異なった経路と考光られる。

鳥羽市で「小豆汁」の回答を得た，小豆汁とはぜんざ いと同種のものであり，餅は丸餅を使用する。

志摩郡阿児町鵜方では「小豆汁」でなく「アンピン」 を食べるといら．アンピンとは餅（直径 $2 \mathrm{~cm}$ 位の一口サ イズの餅）を湯で煮て軟らかくし，小豆餡をのせた餅で その餡をはさみ込むよらにして食べる。

吉川によると, 小豆を用いた雑煮は出雲地方から広が り山陰, 山陽, 越後などの地域でみることができ, 古く は大饗のデザートとして喜ばれたとある11).

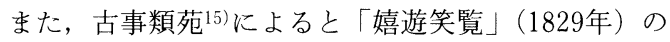
中に「尺素往来に，新年の善哉は，是修正之祝著也とあ り，年の初めに餅を祝らこと聞ゆ，善哉は仏語にてよろ こぶ意あるより取たるべし……‥」と「尺素往来」が15 世紀中頃から後期ごろに書かれた書物であることを考え ると, ぜんざいが正月の，宗教的意味を持っためでたい 食べ物であったとされる。

この鳥羽市，志摩郡の地域も同様な意味を持ったもの であるかどらか不明であるが，地域の古老に起源をたず ねたが明確な回答を得るに及ばなかった。「古くからの 習慣」「小豆はめでたい食べ物」と答えた。

\section{おわりに}

三重の雑煮について郷土誌およびアンケート調査から 検討を行った.

(1) 7 編の郷土誌などから三重の雑煮は「丸餅」「角餅」 「すまし仕立て」「味増仕立て」「小豆」が存在した。

（2）おせち料理がほとんどの家庭で準備されていた(83. $7 \%$ )。しかし，家族構成別では核家族世帯が準備しない 19.1\%を示し，複合家族との問に有意差があった（1\% 有意水準).

（3）雑煮で祝ら家庭が95.6\%を示した．元旦の朝食の契 食率が最も高かった。

（4）雑煮の餅の形は「角餅」が北勢, 中勢および南勢地 域であり,「丸餅」は伊賀, 伊勢志摩および南勢の一部 であった。

（5）雑煮の汁は, 北勢と南勢地域が「すまし仕立て」に 対し中勢および伊賀地域は「味増仕立て」であり，また， 鳥羽市では「アンピン」が食されていた。

謝 辞

最後に調査にご協力いただいた皆様に心から感謝を申 
し上げます。

\section{参考文献}

1)「日本の食生活全集 三重」編集委員会編 : 聞き書三 重の食事，農山漁村文化協会，p.333（1987）

2）大川吉崇 : 三重県の后統料理, 三重フィルド研究会編, p. 175 (1982)

3）大川吉崇 : 安濃町の食生活, 三重民族研究会会報, 22 , pp. 14 15（1997）

4）堀田吉雄, 水谷新左衛門他: 桑名の民族, 桑名市教育委 員会, p.418 (1987)

5）菰野町教育委員会：菰野町史 (下巻), 三重県三重郡菰 野町, p.508 (1997)

6）庄野郷土誌編集委員会：庄野郷土誌, 庄野地区魅力再発 見実行委員会, pp. 368-369（1993）

7）大川吉崇 : 志摩郡 - 和具の食生活, 三重民族研究会会編, p. 203 (1992)

8）大川吉崇：三重県の伝統料理，三重フィルド研究会編， p. 170 (1982)

9）福田アジオ 東京女子大学文理学史学科民俗調査団：水 沢野田町の民俗，絢文社，p.48（1988）

10）堀田千津子, 上住妙, 斎藤智津, 大矢知美江 : 日本栄養 改善学会講演集, p.32（1983）

11）吉川 誠次: 雑煮から見た食文化, 食生活総合研究会誌, 12, 20, pp. 20 27 (1991)

12）大石貞男：東西の食文化，農山漁村文化協会, p. 160 (1989)

13）田畑美穂: 三重ですよろしく, 三重社会経済研究セン タ-, p. 37 (1992)

14）岩井宏實, 奥村彪生：日本の行事食について, 食生活研 究, 9,1 , pp. 15 16 (1988)

15）古事類苑刊行会：古事類苑飲食部, 吉川弘文館, pp. 558 $\sim 559$ (1927) 